\title{
ABSTRACT PRETREATMENT OF WOOD AND CHAR SAMPLES
}

HYMAN SCHULTZ, L. A. CURRIE, F. R. MATSON, and W. W. MILLER

The Pennsylvania State University, University Park, Pennsylvania

It has been shown that contamination from humic acids, chitin, fungal products, etc., contributing young carbon, and from bitumen and carbonate, contributing old carbon, may not be completely removed from wood and char samples by the usual hydrochloric acid and sodium hydroxide pretreatments of the samples. A procedure is offered for the isolation of a pure chemical substance from such samples, cellulose from wood and uncombined carbon from char, that must represent the original material. Cellulose is prepared by boiling the resin-free sample in $1.25 \% \quad \mathrm{H}_{2} \mathrm{SO}_{4}$ and $1.25 \% \mathrm{NaOH}$, adding Schweitzer's reagent, filtering, and precipitating from the filtrate by acidification. Uncombined carbon is separated from char samples as the flocculant precipitate remaining after boiling in $70 \% \mathrm{HNO}_{3}$, followed by settling overnight from a large volume of $6 \mathrm{M} \mathrm{HNO}_{3}$. A simple procedure for the chemical examination of char samples is also offered for the estimation of the amounts of bitumen, carbonate, combined, and uncombined carbon in char.

In a particular example, wood and char samples from the Cape Krusenstern, Alaska site dated at Bern with no pretreatment (B-267A,B: 2500 B.P., Bern II) and at the University of Pennsylvania after an alkali pretreatment (P-404: 2850 B.P., P-400: 3700 B.P., from E. K. Ralph, unpublished) were dated by counting methane made from cellulose extracted from the wood and from uncombined carbon extracted from the char. The fractions so measured are coeval, with a mean age of $4600 \pm 400$ в.P.

Experimental details are contained in the Ph.D. Thesis of Hyman Schultz, The Pennsylvania State University, 1962. Microfilm copies may be obtained from University Microfilms, Inc., Ann Arbor, Mich. A fuller account has been submitted to Analytical Chemistry.

\section{REFERENCE}

Bern II, Gfeller, Oeschger, and Schwarz, 1961, Bern Radiocarbon Dates II : Radiocarbon, v. 3 , p. $15-25$. 